\title{
Exponential Models of Breakthrough Development of Industrial Systems for Achievement of Global Competitiveness
}

\author{
T.O. Tolstykh ${ }^{1}$, E.N. Sheremetyeva ${ }^{2}, E . V$. Shkarupeta $^{3}$ and N.V. Mitropolskaya-Rodionova ${ }^{4, *}$ \\ *Corresponding author: n.v.mitropolskaya-ro@mail.ru \\ ${ }^{1}$ NITU "MISIS", Moscow, Russia \\ ${ }^{2}$ Samara State University of Economic, Samara, Russia \\ ${ }^{3}$ Voronezh State Technical University, Voronezh, Russia \\ ${ }^{4}$ MGIMO University, Moscow, Russia
}

\begin{abstract}
In terms of the Fourth Industrial Revolution, not only the list of end-to-end technologies is changing, but the thinking and methodological approaches to the development of breakthrough scenarios are radically transformed. Obviously, actively recovering industry in next few years will be one of the main drivers of economic growth in Russia. The main conductor of breakthrough development in these conditions will be promising high-growth industrial companies that have the highest leadership potential in both the Russian and global markets. The article reviews the exponential models of the breakthrough development of industrial systems, which will achieve global competitiveness in high-tech markets.
\end{abstract}

Keywords: breakthrough development, technological breakthrough, breakthrough development model.

\section{Introduction}

Achieving global competitiveness, including in industrial production, is one of the main development goals of our country including:

- to ensure the formation in the manufacturing industry of global competitive non-primary sectors, the total share of exports of goods (works, services) which will be at least $20 \%$ of the gross domestic product of the country [1];

- to solve the problem of orientation of industrial policy, including the applied mechanisms of state support, to achieve the international competitiveness of Russian goods (work, services) in order to ensure its presence in foreign markets;

- the entry of the Russian Federation among the five largest economies in the world, etc.

In the Strategy for Scientific and Technological Development [2], the concept of competitiveness itself is considered in relation to other states, that is, only global and international advantages can be obvious advantages in the scientific and technological field and, as a result, in the social, cultural, educational and economic fields. The National Technology Initiative (NTI) sees cooperation with international partners as one of the main principles of its implementation and as the key to the success of domestic high-tech companies in the world of global technologies [3]. Much attention is paid to global competitiveness in the National Innovation Reports $(2015,2016,2017)$.

\section{Problem Statement}

Modern Russia actually had to create a system to support innovation from scratch in a market economy [4]. The basic element of the new infrastructure created to support high-tech projects was the "first generation" of development institutions - RUSNANO, RVK, Skolkovo, the Bortnik Fund. The experience of these organizations was taken into account during the creation of the "second wave" of development institutions - FRIA, ASI, and others. Today, an ambitious task has been set - to sharply increase the share of industrial enterprises that are innovative [5].

Unfortunately, catching up with the leaders is rarely possible. Over the past 50 years, only a few countries have been able to achieve rapid industrialization and sustainable economic growth. In all these cases, the key factor was the industrialization of technology, and these countries have been able to successfully create advanced and technologically capacious industry.

\section{Research Questions}

The need for breakthrough development was voiced by the President of the Russian Federation in his message to the Federal Assembly of March 1st, 2018 and enshrined in the Decree "On the national goals and strategic objectives of the development of the Russian Federation for the period until 2024" The strategic task is the breakthrough development of Russia, the president outlined. 
Under these conditions, the terms "breakthrough development" and "technological breakthrough" have recently become popular, as evidenced by the content analysis of the Internet [6]. However, it is worth noting that the terms in question have been used by researchers in Russia since the late 1990s - early 2000s, which is confirmed by an analysis of the number of scientific publications using the Google Academy service. So, for the first time the term "technological breakthrough" in Russian-language publications appeared in 1997, and the term "breakthrough development" - in 2002.

\section{Purpose of the Study}

In the Strategy of the Scientific and Technological Development of the Russian Federation until 2035, the most significant from the point of view of scientific and technological development avow the emergence of a limited group of leading countries with new production technologies [7].

\section{Research Methods}

Dynamic, accelerated, breakthrough, intense and steady development can be described by the exponential and / or power of the growth curve. In today's world, more and more processes are described by exponential curves. Examples include J-curves of diffusion technologies. Key technologies in the shortest possible time change the productivity of labor, the quality of the products of companies and the speed of their launch to the market. Diffusion (penetration) of technology - the proportion or number of members of society who are beginning to use a new technology or innovation during a certain period of time. Economists at the Bank of England pay attention to the change in the angle of inclination of the diffusion curves [8]. As a result of a change in the J-curves at each new technological level, the effective gain per one unit time will multiply.

\section{Findings}

The economic contour, which is at the previous level of development, during the same period of time achieves a smaller result, both in terms of gross volume and in terms of growth rates. Thus, a number of intermediate findings of the present study can be made [9]:

- it is necessary to carry out breakthrough development on the basis of technological breakthrough;

- breakthrough development must obey exponential laws, since exponential growth ultimately turns out to be faster than any power and linear growth;

- under these conditions, it is necessary to analyze the best-in-class strategic management systems for breakthrough technological development and select an appropriate system model for the existing conditions.

None of the widespread models and systems for managing technological projects does not systematically consider the life cycle of developing and bringing to market a technically complex product. These models, according to the authors, include the following [10]:

- Technology readiness level (TRL) - a technique for assessing the maturity of separate technologies in the process of their development and implementation;

- Gartner Curve - methods of comparative analysis of technologies according to the degree of expected effects and the potential of implementation;

- Gartner Magic Quadrant - methods of comparative analysis of market players by visionary competence and production capacity.

All represented management systems of technological development accompany some issues of creating a technically complex product. In conditions of limited domestic market, it is impossible to use the model of unlimited financial resources and excessive competition; we need a deterministic model to identify priorities and concentrate resources [11].

The development of technically complex products is spiral in nature - several iterations, approximating to the idea of sustainable market products [12]. In case of the market, there is not a spiral, but a coil of spring in the new technological structure. Each separate turn of the technological order of the market passes similar barriers for the product in its development. At the end of this kind of revolution, positioning in the market, requirements for technologies and user scenarios are usually fundamentally refined. This inevitably launches the next round of overcoming new barriers. Most fundamentally new products pass through two development cycles on the average. Yandex unmanned car on the second cycle became a project of unmanned vehicles (on the figure 8 it is the transition $1 \mathrm{C} \rightarrow 2 \mathrm{~B}$ ). The project of a digital cadastre on the second cycle became a project of control over the land turnover $(1 \mathrm{C} \rightarrow 2 \mathrm{~B})$. Ford: 2B. Uber: 1C. Google X: 3A. Tesla: 3A $\rightarrow$ 3B. Quanergy: 1C $\rightarrow$ 2A [13].

Constantly increasing international competition, trade restrictions, as well as the emergence of highly complex scientific and technical problems require from the authorities and development institutions a timely and adequate response to major challenges [14]. In this regard, the role of international and national standards in preserving Russia's scientific and technological identity in the international division of labor and forming the basis for the use of the 
domestic digital industry is increasing. The active participation of stakeholders in the development of regulatory and technical documents is the most important condition for the use of digital technologies in industry.

Today, the leading trend in Russia is to strengthen the interaction of universities and businesses in comparison with other countries of the world. However, to overcome technological barriers in the "market" areas, the degree of university involvement in practical work today is insufficient. World experience shows that one of the promising ways of engagement is to stimulate the creation of university centers for applied research in breakthrough technologies [15]. In Russia, a network of specialized centers of the National Technology Initiative has been formed on the basis of Russian universities and scientific organizations. They develop innovative solutions for the markets of the National Technology Initiative. These solutions will provide global leadership to Russian high-tech companies.

\section{Conclusion}

The exponential growth of data digitization is the basis of the fourth industrial revolution. The key success factor is the ability to react sensitively and quickly to the development of digital technologies and their application in various spheres of life, carrying out the necessary internal and external changes. The future of digital transformation involves not only serious technological, but organizational and even cultural and mental changes.

\section{References}

1. The Department of Corporate Training of Moscow School of Management SKOLKOVO, Digital production: Methods, ecosystems, Rechnologies. Retrieved from: http://assets.fea.ru/uploads/fea/news/2017/11_november/17/tsifrovoe_proizvodstvo_112017.pdf. Accessed: 29.12.2018 (2018). [in Rus.].

2. Decree of the President of the Russian Federation from 01.12.2016 № 642 about Strategy of scientific and technological development of the Russian Federation. Retrieved from: http://kremlin.ru/acts/bank/41449. Accessed: 26.02.2018 (2016). [in Rus.].

3. National technology initiative, Principles of the National Technological Initiative. Retrieved from: http://www.nti2035.ru/nti/. Accessed: 29.12.2018 (2018). [in Rus.].

4. European Commission, Digitising European Industry: 2 years after the launch of the initiative. Brochure, March 2018. Luxembourg: Publications Office of the European Union. Retrieved from: https://ec.europa.eu/digital-singlemarket/en/news/digitising-european-industry-2-years-brochure. Accessed: 29.12.2018(2018).

5. T. Tolstykh, E. Shkarupeta, L.Gamidullaeva, Approaches to designing an innovation ecosystem in the conditions of digitization of socio-economic systems. The Formation of the Digital Economy and Industry: New Challenges. Sankt Petersburg: Iss. Polutechn (2018).

6. Deloitte, Global Manufacturing Competitiveness Index, 2016. Retrieved from: https://www2.deloitte.com/content/dam/Deloitte/global/Documents/Manufacturing/gx-global-mfg-competitivenessindex-2016.pdf. Accessed: 29.12.2018 (2016).

7. President of the Russian Federation, Initiative "Group of twenty" on development and cooperation in the field of digital economy. Retrieved from: http://kremlin.ru/supplement/5111. Accessed: 29.12.2018 (2016). [in Rus.].

8. P. Bilenko, Life in the form of J: risks and possibilities of accelerating the diffusion of technologies. Russia: Forbes (2017). [in Rus].

9.A. Maloletko, A. Bikbulatova, V. Mkrttchian, T. Tolstykh, M. Vinogradova, O. Kaurova, The digital model of the formation of human capital as part of the socioeconomic and spatial reactive projects. Contemporary Problems of Social Work, 4(8), 58-66 (2016).

10. S. Vasin, L. Gamidullaeva, E. Shkarupeta, A. Finogeev, I. Palatkin, Emerging Trends and Opportunities for Industry 4.0 Development in Russia. European Research Studies Journal, XXI(3), 63-76 (2018).

11. T. Tolstykh, E.Shkarupeta, Y. Kostuhin, A. Zhaglovskaya, Digital Innovative Manufacturing basing on Formation of an Ecosystem of Services and Resources. In K.S. Soliman (Ed.), Proceedings of the 31st International-BusinessInformation-Management-Association Conference (IBIMA), (pp. 4738-4746). Milan, Italy: INT Business Information Management ASSOC-IBIMA (2018).

12. B. Bloching, P. Leutiger, T. Oltmanns, C. Rossbach, O. Shafranyuk, The digital transformation of industry. Roland Berger Strategy Consultants und Bundesverband der Deutschen Industrie. München: Roland Berger (2015).

13. World Economic Forum, The Global Risks Report 2018. Retrieved from: http://www3.weforum.org/docs/WEF_GRR18_Report.pdf. Accessed: 29.12.2018. (2018).

14. J. Lee, H. Kao, S. Yang, (2014). Service innovation and smart analytics for industry 4.0 and big data environment. Procedia Cirp, 16, 3-8.

15. D. Schweer, J. Sahl, The digital transformation of industry - the benefit for Germany. The Drivers of Digital Transformation, 3, 23-31 (2017). 